\title{
REPORTS
}

\section{The Works of Japanese Historians in 1983: Business History of Japan}

\author{
By Seishi Nakamura \\ Tokyo Keizai University
}

The works of Japanese business historians in 1983 have the following features.

First, the scope of study is expanding. For example, research on the zaibatsu is spreading from large- to medium-size zaibatsu. The period of study is also moving into more modern periods, including the postWorld War II period. In contrast, studies concerned with the 19th century are declining in number. Moreover, an increasing number of research works are being conducted on modern industries such as automobiles, electric power and electronic machinery which have so far received little attention.

Second, the researchers reveal diverse interests and methods. One notes, however, that most researchers adopt the approaches of economic and industrial historians, while the interaction between business historiography and management science remains minimal. One hopes to see more of the management-scientific approaches adopted in future studies of Japanese business history.

Third, the research works are predominantly case studies, adding more and more to the existing body of historical evidence. The result is an expanding scope of research and a finer partitioning of research themes. This increased division of labor has, one fears, a tendency to diminish the scale of individual researchers' inquiries and discourage interaction among researchers.

\section{Business in the Tokugawa Period}

To begin with, there is Kazuo Yamaguchi, Shiro Matsumoto, Kazuo Sugiyama and Reiko Hayashi's Mitsui Ryogae-dana (Mitsui Exchange House) ${ }^{1}$ ), edited by Nihon Keieishi Kenkyusho (The Japan Business History Institute). This book puts together a general history of the Mitsui Exchange House in the Tokugawa era, which was to become the Mitsui Bank in 1876. Noboru Nishikawa, in Kansei-ki no Mitsui Ryogae- 
dana - Shinmotokata to Sono Kanjo Mokuroku (The Structure of the Mitsui Banking Group and the Accounting Report of Its Central Office, $1775-1800)^{2}$ ), analyzes the accounting and organization of the Mitsui Exchange House from the standpoint of accounting history. Kazuo Yamaguchi's Kahei Kaichu to Mitsui-gumi (Recoinage and Mitsui in the Edo Period) ${ }^{3}$ ) studies the role of the Mitsui Exchange House on the occasion of recoinage by the Tokugawa government. Mataji Miyamoto's Kinginka no Hikikae Gyomu to Sumitomo-ke (Money Exchange Business of the Sumitomo in the Late Tokugawa Period) $)^{4}$ and Kensuke Hiroyama's Kinsei Koki ni okeru Konoike-ke no Hokonin (The Employees of the House of Konoike during the First Half of the 19th Century) ${ }^{5}$ ) are concerned with the business of the prominent merchants in western Japan.

Toshikazu Nakase has been pursuing the important question of how the major merchant families of the Tokugawa period coped with the hostile business environment during the turbulent final years of the Tokugawa government. Nakase's Oshio Jiken o meguru Tokkenteki Monbatsu Chonin to Shomin-so no Doko (The Impact of Heihachiro Oshio's Uprising on the Elite Merchants and Usury Capitalists and the Commoners' Anti-Bakufu Movement) ${ }^{6}$ ) and Kaiko to Kaei-Ansei-ki ni okeru Sumitomo Mitsui no Kasei Kaikaku (Sumitomo and Mitsui's Organizational Reforms in the Kaei and Ansei Period 1848-1857)7) are the fruits of his 1983 research.

Turning from urban to local merchants, one finds Eiichiro Ogura, who wrote Himono Tonya Kojima-ke no Kessan (Financial Statements of the Kojima Family, the Dried Fish Wholesaler of Omi), ${ }^{8)}$ Masatoshi Amano, Tokugawa Koki ni okeru Awa Aisho no Chikuseki Kozo (1), (2) (Capital Accumulation by an Awa Indigo Merchant in the Later Tokugawa Period - The Case of the House of Miki) ${ }^{9}$ ), Akira Hasegawa, Bakumatsu-ki Shoyu Jozogyo ni okeru Koyo Rodo to Chingin - Banshu Tatsuno Maruo-ke no Baai (Employment and Wages in a Soybean Sauce Brewer in the Late Tokugawa Period: The Case of the Maruo Family in Tatsuno), ${ }^{10)}$ and Masahiro Uemura, Kinsei Setouchi Kaiun Kino no Ichikosatsu (The Development of the Shipping Business in the Shiwaku Islands under the Ninmyo System. ${ }^{11}$ ) Shinshi Kataoka, in Edoki no Shogyo, Shonin-Kyoiku, Shonin-gaku (Business and Merchant Training in the Tokugawa Period), ${ }^{12)}$ studies business education in the Tokugawa period, providing information on the textbooks used for the training.

\section{Histories of the Zaibatsu}

The most significant publication in this category is by Shoichi 
Asajima, Senkan-ki Sumitomo Zaibatsu Keieishi (Sumitomo Zaibatsu During the Interwar Years. ${ }^{13}$ ) Utilizing Sumitomo's unpublished financial data, Asajima performs a detailed analysis of the cash management by Sumitomo's family firms. Besides offering an illuminating financial analysis of the Sumitomo zaibatsu, the book proposes a method for comparative financial analysis of different zaibatsu groups. This book raises the standards of research on Sumitomo to a level equal to those on Mitsui and Mitsubishi.

On the other hand, Kanji Ishii's Ginko Sosetsu Zengo no Mitsui-gumi (The Crisis of the Mitsui Group around the Time of the Founding of the Mitsui Bank) ${ }^{14}$ ) deals with Mitsui's managerial difficulties in the early Meiji period and their solutions. Yutaka Kasuga's 1930 Nendai ni okeru Mitsui Bussan Kaisha no Tenkai Katei - Shohin Torihiki to Shagai Toshi o Chushin ni (2) (The Development of the Mitsui Trading Company in the 1930s) ${ }^{15}$ ) and Kunio Suzuki's Senji Keizai Tosei-ka no Mitsui Bussan (1) (The Mitsui Trading Company in the Period 19371945) ${ }^{16)}$ offer new information on Mitsui Trading Company. Both articles make abundant use of the company's internal data and contribute significantly to the enhancement of research on Mitsui Trading. As for the Mitsubishi zaibatsu, one finds Takaaki Suzuki's Meiji 10 Nendai Yubin Kisen Mitsubishi Kaisha no Kanri Keitai (The Administrative Structure of the Mitsubishi Postal Shipping Company in the Early Meiji Period). ${ }^{17 \text { ) }}$

Besides these studies of the larger zaibatsu, studies of medium-size zaibatsu are beginning to emerge. The study of the Yamaguchi zaibatsu, among others, has made great strides thanks to Yasuo Mishima. This Yamaguchi Zaibatsu is a medium-size zaibatsu in the western part of Japan which has developed around the Yamaguchi Bank and spread into the fields of finance and insurance. Mishima's three papers, Yamaguchi Zaibatsu no Seiritsu Zenshi (A Background History of the Emergence of the Yamaguchi Zaibatsu), ${ }^{18}$ ) Yamaguchi Zaibatsu no Takakuka Senryaku (Diversification Strategy of the Yamaguchi Zaibatsu) ${ }^{19)}$ and Yamaguchi Zaibatsu no Hatten to Kaitai (The Development and Dissolution of the Yamaguchi Zaibatsu) ${ }^{20}$ ) trace out the birth, growth and dissolution of the Yamaguchi zaibatsu. One looks forward to increased research efforts on medium-size local zaibatsu in the future.

Lastly, there has been a surge of interest to place zaibatsu in an international perspective. Shigeaki Yasuoka, in Nihon no Dozokuteki Daikigyo no Seikaku (The Character of Large Family Companies of Japan), ${ }^{21)}$ examines the internal structure of Japan's family-style large firms and proposes a comparative analysis of the character of these 
family firms in an international perspective. Masahiro Kudo, in his Nihon Zaibatsu no Kaitai ni Kansuru Ichikosatsu (An Analysis of the Dissolution of the Zaibatsu of Japan), ${ }^{22}$ ) deals with the dissolution of zaibatsu after World War II.

\section{Manufacturing and Mining}

One can observe a number of articles on the development of modern Japan's industries written from the viewpoint of entrepreneurship. In textiles, Yukio Okamoto and Kenji Imazu (editors), Meiji Zenki Kanei Kojo Enkaku - Senju Seijusho, Shinmachi Bosekisho, Aichi Bosekisho (Historical Materials on the Governmental Enterprises in Meiji Japan - Senju Woolen Mills, Shinmachi Spinning Mills and Aichi Spinning Mills), ${ }^{23}$ ) compiles the data on the governmental mills in the early Meiji period. Yukio Okamoto's Nisshin-Sengo no Chiho Boseki Kigyo no Tenkai (The Development of Cotton-Spinning Enterprises in the District of Kyushu in the Post-Sino-Japanese War Years), ${ }^{24)}$ studies the activities of the local firm Hakata Cotton and Silk-Spinning Company. Yutaka Taniguchi's Showa Shoki ni okeru Hompo Menbosekigyo no Gorika Katei (The Rationalization Process of the Cotton-Spinning Industry in Japan in the Early Showa Era), ${ }^{25)}$ and Takeo Izumi, in Showa Kyoko-ki ni okeru Nihon Menshi-Bosekigyo no Doko (A Study of the Japanese Cotton-Spinning Industry during the Showa Depression), ${ }^{26)}$ examine the rationalization measures adopted by the cottonspinning industry during the 1920 s and 30 s. On weaving, one finds Minoru Sugihara's Nihon Sangyo-shi - Meiji Jidai Koki no Kigyo Keiei (History of Japanese Industry - The Management of Textile Manufacturing in the Latter Meiji Era) ${ }^{27)}$ and Takeshi Abe's Senzen-ki Sennan Menorimonogyo ni okeru Sanchi Daikeiei - Obitani Shoten no Bunseki (Large Cotton Weavers in Prewar Japan - An Analysis of Obitani Shoten in the Cotton Weaving District of Sennan, Osaka). ${ }^{28)}$ Shigeaki Yasuoka, Gairai Gijutsu no Juyo to Zairai Seisan no Tenkan Noryoku (Adaptability of Traditional Cotton Spinning to Western Technologies in Late 19th Century Japan ${ }^{29}$ ) studies the introduction and adaptation of Western technologies compared to Japan's traditional method.

With the new focus of industrial historiography on the period between the wars, research on heavy industries have shown a marked increase in recent years. In the steel industry, Bunji Nagura's Nihon Kokan Kabushiki Kaisha no Setsuritsu Hatten Katei (The Establishment and Development of the Nihon Kokan (Steel Tube) Kabushiki Kaisha) ${ }^{30}$ ) is a case study of a representative steel firm in prewar Japan. Koichi Hasebe, in Meiji-ki Riku-Kaigun-Kosho ni okeru Tokushuko Seisan Taisei no 
Kakuritsu (The Establishment of the Special Steel Production System in the Army and Navy Arsenals in the Meiji Period), ${ }^{31}$ ) concerns himself with the steel production at the military arsenals. Osamu Nagashima, Nittetsu Seiritsu igo no Karuteru Saihensei (1)-(4) (Reorganization of the Iron and Steel Cartel in Japan after the Foundation of the Nihon Seitetsu Corporation) ${ }^{32}$ ) and Nihon Seitetsu Kabushiki Kaisha no Keiei Kozo (1)-(4) (The Structure of the Nihon Seitetsu Corporation) $)^{33)}$ bring to light the behavior of the Japanese steel industry during the 1930s.

In the field of shipbuilding, Takao Shiba, Fukyo-ki no Nidai Zosen Kigyo (A Comparative Study of the Two Big Firms in Japanese Shipbuilding Industry during the Depression after World War I), ${ }^{34)}$ looks at the shipbuilding enterprises during the depression period, compares the strategies of Mitsubishi Shipbuilding and Kawasaki Dockyards, and argues how the difference in strategies led to the different growth performances of the two companies. Yukio Yamashita, in Senkan-ki no Kaiun to Zosengyo (The Shipping and Shipbuilding Industries in the Interwar Years), ${ }^{35)}$ documents the shipbuilders' efforts to survive the depression. Takeaki Teratani's "Nihon Kaigun to Yokosuka Kaigun Kosho" (The Japanese Navy and Yokosuka Navy Arsenals) ${ }^{36)}$ studies warship building in the same period.

As for the electrical machinery industry which grew rapidly since the 1910s, Shin Hasegawa, Denki Kikai Kogyo no Keisei to Hatten (Historical Development of the Electric Machinery Industry in Japan) ${ }^{37}$ ) and Judenki Kasen Taisei no Seiritsu to Tenkai (The Electrical Equipment Cartel in the Interwar Period), ${ }^{38)}$ study the formation of an oligopolistic structure in the 1930s among Shibaura, Hitachi, Mitsubishi and Fuji.

In the newly formed automobile industry one finds Masaru Udagawa's Historical Development of the Japanese Automobile Industry, 19171971: Business and Government ${ }^{39)}$ and Senzenki no Nihon Jidosha Sangyo (The Japanese Automobile Industry Before World War II), ${ }^{40)}$ as well as Masachika Shinomiya's Ryotaisenkan-ki ni okeru Zainichi Gaishikei Jidosha Kaisha no Keiei Katsudo (American Business in Japan in the Interwar Period - The Case of Japan Ford and Japan GM). ${ }^{41}$ )

In chemicals, Juro Hashimoto, Senkan-ki no Kagaku Kogyo (The Chemical Industry in Japan in the Interwar Years), ${ }^{42)}$ deals with the ammonium sulphate industry, while Yutaka Taniguchi, Daiichiji Sekai Taisen-ki ni okeru Hompo Gosei Senryo Kogyo no Seiritsu (The Rise of the Synthetic Dye Industry in Japan during World War I), ${ }^{43)}$ addresses itself to the synthetic dye industry. 
The electrical industry has been receiving increasing attention in recent years. Masaki Yoshida, Dento Sangyo Hatten ni okeru Chukan Shonin no Yakuwari (The Role of Merchants in the Development of the Japanese Electrical Industry, 1900-1930), ${ }^{44)}$ looks at the role of the Kawasaki Electric Company and other promoters who undertook contract works for founding and managing of local small-size electrical companies. Takeo Kikkawa, Nichirosengo-ki no Nichi-Ei Goben Denryoku Kaisha Koso (The Scheme for a Joint Japanese-English Electric Power Company after the Russo-Japanese War), ${ }^{45}$ ) and Tetsuro Watari, Kansai ni okeru Denryoku Dokusentai no Keisei (The Formation of an Electric Power Monopoly in the Kansai District: The Case of the Kyoto Electric Light Company) ${ }^{46)}$ also deserve mention.

In the field of mining, several authors deal with the coal mining industry in the Meiji Era. Senzo Hidemura's Meiji Shoki Hizen Taku ni okeru Tanko Keiei no Ichikosatsu (Coal Mining Business in Hizen Taku in the Early Meiji Era), ${ }^{47)}$ Takashi Imano's Meiji 20 Nen-zengo ni okeru Chikuho Sekitan Kogyo (The Coal Mining Industry in the Chikuho District in the Middle Years of the Meiji Era), ${ }^{48)}$ and Nobumasa Tojo's Meiji Chuki no Aso Namazuda Tanko ni kansuru Ichikosatsu (The Aso Namazuda Coal Mine in the Mid-Meiji Era) ${ }^{49)}$ examine coal mining in the Kyushu District. Hiroshi Ichihara, Daiichiji Taisen ni itaru Hokutan Keiei (Business Activities of the Hokkaido Coal and Shipping Company Before World War I), ${ }^{50}$ ) examines the circumstances under which the Hokkaido Coal and Shipping Company joined the Mitsui group.

\section{Railways and Shipping}

First, in railways, Yoshinobu Oikawa, Meiji-ki Chiho Tetsudo-shi Kenkyu (A Study of the History of Local Railways in the Meiji Japan), ${ }^{51}$ ) follows the development of local railways in the Kanto District during the Meiji period. Katsumasa Harada's Nihon no Kigyoka to Tetsudomo no Keisei (Industrialization and the Construction of Railway Networks in Japan) ${ }^{52}$ ) is a case study of the Nihon Railway Company.

Second, in the shipping industry, Hiromi Masuda's Shokusan Kogyo Seisaku to Kasen Sen-un (Japan's Industrial Development Policy and River Transportation), ${ }^{53)}$ is a study of the early Meiji period. Kozaburo Kato's "Sangyo Shihon Kakuritsu-ki no Nihon Kaiun" (The Shipping Industry During the Formative Years of Japan's Industrial Capitalism), ${ }^{54}$ ) points out the vital role of shipping in the development of the cottonspinning industry. William D. Wray, "Senkai-ki ni okeru kigyo no Jishusei to Yu-Sho Teikei Mondai" (Company Autonomy and N.Y.K.O.S.K. Cooperation in the Interwar Years) ${ }^{55}$ ), studies the merger negotia- 
tions between NYK and OSK during the interwar years and points out how considerations for company autonomy got in the way of the merger. One notices an increasing research output on shipping in recent years and can expect the trend to continue in the future.

\section{Finance}

Many studies in this field have conventionally taken the form of case studies. The 1983 additions of the history of local banks include Kazunobu Okada's Hamametsu Dai-nijuhachi Kokuritsu Ginko no Seiritsu to Shuen (A Life History of the 28th National Bank of Hamamatsu, 1878-1889), ${ }^{56)}$ Hiroshi Matsumoto's Shizuoka-ken Mikuriya Ginko no Tenkai Katei (The Development of the Mikuriya Bank in Shizuoka Prefecture, 1895-1914), ${ }^{57)}$ Masao Noda's Takada Nosho Ginko Oboegaki (A Note on the Takada Agricultural and Commercial Bank), ${ }^{58)}$ and Shoichi Asajima's Taisho-ki ni okeru Hachiman Ginko Teiki-Yokin Bunseki (Time Deposits of the Hachiman Bank in Shiga Prefecture, 1915-1926). ${ }^{59)}$ Ikuo Tanaka's Ohara Magosaburo no Ginko Seisaku (Magosaburo Ohara: A Country Banker), ${ }^{60}$ ) focuses on the life of a noted textile magnate as a country banker. Mention must also be made of Toshihiko Kato (editor), Nihon Kinyuron no Shiteki Kenkyu (Survey of Historical Studies of the Japanese Financial Industry). ${ }^{61 \text { ) }}$

In the trust business, Shoichi Asajima's two articles, Toyama-ken Shin takugyo no Seisei to Togo (1), (2) (Growth and Consolidation of the Trust Business in Toyama Prefecture) ${ }^{62)}$ and Niigata-ken Shintakugyo no Seiritsu to Hatten (Development of the Trust Business in Niigata Prefecture $),{ }^{63)}$ deal with the early history of local trust business. In the relatively unresearched field of security business, Yasuhiro Mori, in Sogo Shoken Kaisha no Seiritsu Katei (Security Companies of Japan), ${ }^{64)}$ uses the three cases of leading security companies as a generic model of Japanese security companies and draws some general conclusions. In the insurance business, Kazuo Sugiyama, Showa Senzen-ki ni okeru Zaibatsu Seiho Kaisha no Kabushiki Shasai Shoyu (Security Holdings of Zaibatsu Life Insurance Companies, 1926-1936), ${ }^{65)}$ examines the investment strategies of the Mitsui, Meiji, Sumitomo and Yasuda Life Insurance companies.

\section{Businessmen and Business Philosophy}

Studies of business personalities have always been an important part of business history. Makoto Seoka has successfully applied the "Theory of the Reference Group" to the study of zaibatsu leaders in the past several years. The following four articles are Seoka's output in 1983: 
Shuyodan to Zaibatsu Keieisha (1) (The Shuyodan and the Zaibatsu Managers); ${ }^{66)}$ Hotokukai to Zaibatsu Keieisha (The Hotokukai and the Zaibatsu Managers - An Analysis of "Shimin" in the Approach to Entrepreneurial History); ${ }^{67)} 1930$ Nendai no Sumitomo no Kigyoshashiteki Kenkyu (2) (A Study in the Entrepreneurial History of the Sumitomos in the 1930s); ${ }^{68)}$ and Nishida Kitaro to Zaibatsu Keieisha (1) (Kitaro Nishida and the Zaibatsu Managers - A Reference Group's Theoretic Approach). ${ }^{69)}$ In these articles Seoka studies the tenets and behavior of Masatsune Ogura and other managers in relation to Shuyodan, Hotokukai and other social groups surrounding them. Keiji Muramatsu's Mitsui no Hayakawa Senkichiro to Hotoku (Hotokuism and Mitsui's Senkichiro Hayakawa), ${ }^{70}$ ) is a study based on motivation similar to Seoka's. Jiro Saito, Daiki Keieisha no Keiei Rinen (Entrepreneurial Spirit of the Daiki Company in Early Days), ${ }^{71}$ ) focuses on the business philosophy of Seishu Iwashita. Satoshi Saito, in Okochi Masatoshi ni okeru Keiei Rinen no Keisei (Formation of Management Philosophy in Masatoshi Okochi), ${ }^{72)}$ deals with Masatoshi Okochi, the founder of the Riken Concern. Hidemasa Morikawa (editor), Makita Tamaki Denki Shiryo (Documents on the Life of Tamaki Makita), ${ }^{73)}$ collects the diaries and memos of Tamaki Makita who rose from a mining engineer to a top executive of the Mitsui organization.

Other studies on the subject include Yotaro Sakudo's. Kansai-kei Kigyoka no Rekishiteki Tokushitsu (Historical Characteristics of Entrepreneurs of the Kansai Area) ${ }^{74}$ ) and Toshimitsu Asano's Nihon no Kindaika to Zitsugyo no Shiso (Japan's Modernization and the Growth of the Notion of "Business"). ${ }^{75)}$ Sakudo attributes certain common characteristics of the business managers from the Kansai area to its business climate. Asano's article traces out the process of transition in business philosophy from traditional mercantilism to modern business ideology.

\section{Labor Management and Industrial Relations}

Research in this field shows a heavy concentration on the industrial relations within large-scale firms in mining and heavy industries in the post-World War I period. The reason is that the Japanese family-style labor management system was established in these sectors during this period - after the surge in the labor movement during World War I. For example, Hidetoshi Sato, Taisho-ki ni okeru Fujita-gumi Kosaka Kozan no Romu Kanri ni tsuite" (Two Strike Incidents in Fujita-gumi Kosaka Mine in the Taisho Era), ${ }^{76}$ ) documents the labor disputes of the company and their effects on the company's labor management policy. 
Hiroshi Ichihara, Daiichiji Taisen-go no Sandogyo Roshi Kankei no Tenkai - Furukawa Ashio Kogyosho o Sozai toshite (The Development of Industrial Relations in Copper Mining after the First World War), ${ }^{77}$ ) also points out that stable labor relations were formed in the postwar period at the Ashio mine of the Furukawa Mining Company. Kazuo Saguchi, Daiichiji Taisen-go no Roshi Kankei no Tenkai - Mitsui Miike Kyoai Kumiai no Keisei to Saiken ni sokushite (1), (2) (Development of Industrial Relations after World War I), ${ }^{78}$ ) studies the labor management problems at the Miike mine of Mitsui Mining Company. In heavy industries, the same subject is pursued by Kazuo Saguchi: Daiichiji Taisen-go no Kaigun Kosho ni okeru Roshi. Kankei no Tenkai (Development of Indistrial Relations in Naval Arsenals after World War I). ${ }^{79}$ ) Yutaka Nishinarita, Daiichiji Taisen chu go no Zaibatsu-kei Zosen Kigyo no Roshi Kankei - Mitsubishi Nagasaki Zosensho no Rodo Sogi Bunseki (Industrial Relations in a Zaibatsu Shipbuilding Company during and after World War I - An Analysis of Labor Disputes at the Mitsubishi Nagasaki Shipyard), ${ }^{80}$ ) shows how the labor movement was absorbed into a paternalistic labor management policy of the company. Yukihiro Shoji's "Sangyo Gorika-ki no Sagyo Shudan to Romu Seisaku" (Working Groups and Labor Management in the Industrial Rationalization Process - The Case of a Railway Factory (Naebo and Morioka) in the Early Showa Era), ${ }^{81)}$ is also worth noting.

As for the Meiji period, Nakamigawa Hikojiro no Shiyonin Taigu no Rinen (Personnel Management of Hikojiro Nakamigawa in the 1870s) ${ }^{82}$ ) by Akiko Chimoto, and Meiji Chu-ko-ki Hompo Menshi Bosekigyo ni okeru Ukeoisei no Rekishiteki Seikaku (The Historical Character of the Contract System of the Japanese Cotton Industry in the Meiji Era The "Rengo" Contract System Reconsidered) ${ }^{83)}$ by Kozaburo Kato, are noteworthy. The field of industrial relations has not received the attention with regard to research that it deserves. One hopes for more output in this field in the future.

\section{Business History of the Post-World War II Period}

A notable feature of the publications which appeared in 1983 is the abundance of research on the period after World War II. One reason for the surge of interest in this period might be the lapse of 40 years since the war, which is turning that time into history. Another reason might be the desire to explain the high growth of the Japanese economy in this period in terms of the behavior of Japanese firms and their managers.

A comprehensive work on this subject is found by the Meiji Daigaku Kigyo Keiei Kenkyukai (The Meiji University Study Group of Business 
Management): Sengo Kigyo Keiei no Hensen to Kadai (Business Management in Japan Since World War II.) ${ }^{84)}$ This book is the result of the joint efforts of 15 scholars and covers a wide range of topics including business strategy, business organization, corporate finance, labor management, marketing and technology. Toshio Sumiya's Sengo Nihon no Kigyo Keiei (Business Management in Japan Since World War II) ${ }^{85}$ ) offers another survey of postwar Japanese business management.

The Business Review, edited by the Hitotsubashi University Institute of Business Research, has a special issue (Vol. 31, No. 2) on the development in Japan since World War II.) ${ }^{84)}$ This book is the result of the Shin-ichi Yonekawa, Keiichiro Nakagawa, Seiichiro Yonekura, Koichi Shimokawa and Masumi Tsuda. Yonekawa's Sengo Sen-i Kigyo no Seicho to Senryaku (The Postwar Growth and Strategy of CottonSpinning Enterprises: A Comparative Study) ${ }^{86}$ ) is an international comparative study which looks at Japan, the USA and the UK. Nakagawa's Sengo Nihon no Kaiun to Zosen (Shipping and Shipbuilding in Postwar Japan: A Sketch of Business History) ${ }^{87)}$ stresses the interdependent pattern of growth of the shipping, shipbuilding and steel industries. Yonekura's Sengo Nihon Tekkogyo Shiron (An Insight into the Postwar Japanese Steel Industry: Its Continuity and Discontinuity with Prewar History ${ }^{88}$ ) attempts to identify the old and new elements in postwar Japanese business using the steel industry as an example. Koichi Shimokawa's Sengo Nihon Jidosha Sangyo Keieishi ni tsuite (Notes on the Business History of the Postwar Japanese Automobile Industry) ${ }^{89}$ ) stresses the role of rationalization efforts behind the strong international competitiveness of the Japanese automobile industry. Tsuda's Sengo Keiei to Roshi Kankei - Sono Hatten no Rekishiteki Igi (Industrial Relations and Postwar Business Management: Its Impact on Japanese Management History) ${ }^{90)}$ takes an industrial relations approach to postwar business management and, through an examination of the labor movements in $1945-46$, stresses the difference in labor relations between the prewar and postwar periods.

Other studies of postwar industries include Seiichiro Yonekura's Sengo Nihon Tekkogyo ni okeru Kawasaki Seitetsu no Kakushinsei (Innovative Behavior of the Kawasaki Steel in the Postwar Japanese Steel Industry $)^{91)}$ and Hiroaki Yamasaki's Kawasaki Sekiyu Kagaku Konbinato no Seiritsu to Tenkai (Formation and Development of the Kawasaki Petrochemical Complex). ${ }^{92)}$ Toyoaki Ono takes a management scientific approach in his Nihon Kigyo no Ishi Kettei System (The Japanese Corporate Decision-Making System), ${ }^{93)}$ stressing the modernization of corporate decision-making during the postwar period. 
At any rate, the postwar developments of Japanese industries and firms offer many research topics for business historians. One has so far witnessed merely the beginning of research efforts in this area and can confidently predict a flourishing of research activities in the future.

\section{Other Works}

Shin-ichi Yonekawa pursues, in Sogo Shosha Keisei no Ronri to Jittai (Theory and Reality behind the Emergence of General Trading Companies: A Comparative Study), ${ }^{94}$ ) the historical logic behind the emergence of general trading companies in Japan. He points out, in comparison with the UK and US situations, that the environment of Japanese industrialization was conducive to their growth. One hopes to see more works of this type in the future along with the conventional empirical case studies.

In the area of the history of economic groups, there is Yoshiro Takahashi's Wagakuni ni okeru Shoko Kaigisho no Senku Keitai (Pioneer Period of the Chamber of Commerce Law in Japan). ${ }^{95)}$ This paper traces out the proceedings leading to the Chamber of Commerce Law in Yokohama. There is also Ikuo Hara's Keirishi-ho Kaisei Undo no Tenkai (1) (2) (3) (Revisions of the Professional Accountants' Act of Japan). ${ }^{96)}$

Tsunehiko Yui and Mark Fruin's Nihon Keieishi ni okeru Saidai Kogyo Kigyo 200-sha (The 200 Largest Industrial Enterprises of Japan $)^{97)}$ lists the 200 largest industrial enterprises, by assets, for the years 1918, 1930 and 1954. This will prove to be useful basic material for researchers on Japanese business history. Yasushi Goto, in Nihon Shihonshugi Kakuritsu-ki no Shihonka Meibo (The Japanese Capitalists, 1905-1915), ${ }^{98)}$ lists the largest shareholders in Japan for the period 1905-1915. In Taisho Shoki no Dai-shisanka Meibo (Men of Great Fortunes in Japan in the Early Taisho Period), ${ }^{99}$ ) by Ryuichi Shibuya, Shojiro Ishikawa and Satoshi Saito, lists the names of the wealthiest individuals in Japan for the same period.

Finally, a few words on management history. Recent years have witnessed an increased interest in the system of Japanese business, especially in its historical roots. Yasuzo Horie's Nihonteki Keiei no Shudan-shugi to sono Rutsu (Groupism of Japanese Business and Its Roots) ${ }^{100)}$ discusses groupism as a central feature of the Japanese business system and offers a critical survey of the literature available on the subject. Takenori Saito's Ueno Yoichi - Hito to Gyoseki " (Yoichi Ueno: Man and His Works) ${ }^{101}$ ) is a biography of Yoichi Ueno, translator and introducer of F.W. Taylor's Principles of Scientific Management, 
published in commemoration of the 100th anniversary of Ueno's birth.

\section{Notes}

1) Mitsui Bank, Co. Ltd., 1983.

2) Keizai Ronshu (The Economic Review), Vol. 16, No. 3, Saga University, 1983.

3) Soka Keiei Ronshu (The Review of Business Administration), Vol. 8, No. 1, Soka University, 1983.

4) Osaka Daigaku Keizaigaku (Osaka Economic Papers), Vol. 33, No. 1-2, Osaka University, 1983.

5) Osaka Daigaku Keizaigaku (Osaka Economic Papers), Vol. 32, No. 2-3, Osaka University, 1983.

6) Osaka Sangyo Daigaku Ronshu (Journal of Osaka Industrial University, Social Sciences), No. 59, Osaka Industrial University, 1983.

7) Osaka Sangyo Daigaku Ronshu (Journal of Osaka Industrial University, Social Sciences), No. 58, 1983 .

8) Hikone Ronso, No. 222-223, Shiga University, 1983.

9) Ehime Keizai Ronshu (Ehime Economic Journal), Vol. 2, No. 2, Vol. 3, No. 1, Ehime University, 1982-1983.

10) Keizai Keiei Ronshu (Economic and Business Review), Vol. 25, No. 2-3, St. Andrew's University, 1983.

11) Osaka Daigaku Keizaigaku (Osaka Economic Papers), Vol. 33, No. 1-2, Osaka University, 1983.

12) Keizai Keiei Ronshu (Journal of Economic and Business Studies of Ryukoku University), Vol. 23, No. 3, 1983.

13) Tokyo Daigaku Shuppankai (University of Tokyo Press), 1983.

14) Mitsui Bunko Ronso (Journal of Mitsui Research Institute for Social and Economic History), No. 17, 1983.

15) ibid.

16) ibid.

17) Keizai Ronshu (Economic Journal), No. 35, Daito Bunka University, 1983.

18) Konan Keiei Kenkyu (Konan Business Review), Vol. 23, No. 2, Konan University, 1983.

19) Konan Keiei Kenkyu, Vol. 24, No. 1, 1983.

20) Keiei Shigaku (Japan Business History Review), Vol. 18, No. 2, 1983.

21) Doshisha Shogaku (Doshisha Business Review), Vol. 34, No. 5, Doshisha University, 1983.

22) Chuo Daigaku Kigyo Kenkyusho Nempo (Annual Bulletin of the 
Institute of Business Research), Chuo University, No. 4, 1983.

23) Toyo Bunka-sha, 1983.

24) Seinan Gakuin Shogaku Ronshu (Commercial Review of Seinan Gakuin University), Vol. 29, No. 3-4, 1983.

25) Keizaigaku Kenkyu (Journal of Economic Studies), No. 26, Graduate School of the University of Tokyo, 1983.

26) Senshu Keizaigaku Ronshu (Economic Bulletin of Senshu University), Vol. 18, No. 1, 1983.

27) Seinan Gakuin Shogaku Ronshu (Commercial Review of Seinan Gakuin University), Vol. 29, No. 3-4, 1983.

28) Shakaikagaku Kenkyu (Journal of Social Sciences), Vol. 35, No. 1, University of Tokyo, 1983.

29) Doshisha Shogaku (Doshisha Business Review), Vol. 35, No. 3, Doshisha University, 1983.

30) Kanagawa Kenshi, Sangyo-Keizai-hen (History of Kanagawa Prefecture: Industry and Economy), 1983.

31) Keizaigaku Kenkyu (Economic Studies), Vol. 33, No. 3, Hokkaido University, 1983.

32) Ritsumeikan Keieigaku (Ritsumeikan Business Review), Vol. 21, No. 4, Vol. 21, No. 5, Vol. 21, No. 6, Vol. 22, No. 1, Ritsumeikan University, 1982-1983.

33) Ritsumeikan Keieigaku, Vol. 22, Nos. 3-6, 1983-1984.

34) Keiei Shigaku (Japan Business History Review), Vol. 18, No. 3, 1983.

35) Shogaku Ronsan (Journal of Commerce), Vol. 24, No. 5-6, Chuo University, 1983.

36) Kanagawa Kenshi, Sangyo-Keizai-hen, 1983.

37) ibid.

38) Hokei Kenkyu (Journal of Law and Economics), Vol. 32, No. 1, Shizuoka University, 1983.

39) Keiei Shirin (Hosei Journal of Business), Vol. 19, No. 4, Hosei University, 1983.

40) Kanagawa Kenshi, Sangyo-Keizai-hen, 1983.

41) Keieigaku Kenkyu Ronshu (Graduate Studies in Business Administration), No. 2, Graduate School of Seinan Gakuin University, 1983.

42) Kanagawa Kenshi, Sangyo-Keizai-hen, 1983.

43) Shakai Keizai Shigaku (Socio-Economic History), Vol. 48, No. 6, 1983.

44) Mita Shogaku Kenkyu (Mita Business Review), Vol. 25, No. 5, Keio University, 1982. 
45) Energy-shi Kenkyu, No. 12, 1983.

46) Keizai Ronso (Economic Review), Vol. 131, No. 1-2, Kyoto University, 1983.

47) Energy-shi Kenkyu, No. 12, 1983.

48) ibid.

49) ibid.

50) Hitotsubashi Ronso (Hitotsubashi Review), Vol. 90, No. 3, Hitotsubashi University, 1983.

51) Nihon Keizai Hyoron-sha, 1983.

52) Shakai Keizai Shigaku (Socio-Economic History), Vol. 48, No. 5, 1983.

53) ibid.

54) ibid.

55) Keiei Shigaku (Japan Business History Review), Vol. 18, No. 2, 1983.

56) Kinyu Keizai (Journal of Financial Economics), No. 200, 1983.

57) Chiho Kinyu-shi Kenkyu (Historical Studies of Local Finance), No. 14, 1983.

58) Kinyu Keizai, No. 199, 1983.

59) ibid., No. 202, 1983.

60) ibid., No. 203, 1983.

61) Tokyo Daigaku Shuppan-kai (University of Tokyo Press), 1983.

62) Shintaku (Journal of Trust Business), No. 131, No. 133, 1982-83.

63) ibid., No. 135, 1983

64) Shogaku Ronkyu (Journal of Business Administration), Vol. 31, No. 1, Kwansei Gakuin University, 1983.

65) Keizai Gakubu Ronshu (Journal of the Faculty of Economics), Vol. 14, No. 1, Seikei University, 1983.

66) Kyotogakuen Daigaku Ronshu (Kyotogakuen University Review), Vol. 11, No. 2, 1983.

67) ibid., Vol. 11, No. 3, 1983.

68) ibid., Vol. 12, No. 1, 1983.

69) ibid., Vol. 12, No. 2, 1983.

70) Hamamatsu Tanki Daigaku Kenkyu Ronso (Collected Papers, Hamamatsu Tanki Daigaku), No. 28, Hamamatsu Junior College, 1983.

71) Kyotogakuen Daigaku Ronshu, Vol. 11, No. 2, 1983.

72) Keiei Shigaku (Japan Business History Review), Vol. 18, No. 3, 1983.

73) Japan Business History Institute, 1983.

74) Osaka Daigaku Keizaigaku (Osaka Economic Papers), Vol. 32, 
No. 2-3, Osaka University, 1983.

75) Shokei Ronshu (Journal of Business and Economics), No. 45, Graduate School of Waseda University, 1983.

76) Konan Ronshu (Papers on Social Sciences), No. 11, Graduate School of Konan University, 1983.

77) Rekishigaku Kenkyu (Journal of Historical Studies), No. 522, 1983.

78) Nihon Rodo Kyokai Zasshi (Monthly Journal of the Japan Institute of Labor), Vol. 25, No. 2, No. 3-4, 1983.

79) Keizaigaku Kenkyu (Journal of Economic Studies), No. 26, Graduate School of the University of Tokyo, 1983.

80) Hitotsubashi Ronso (Hitotsubashi Review), Vol. 90, No. 3, Hitotsubashi University, 1983.

81) Keizaigaku Kenkyu (Economic Studies), Vol. 33, No. 3, Hokkaido University, 1983.

82) Doshisha Shogaku (Doshisha Business Review), Vol. 35, No. 2, Doshisha University, 1983.

83) Senshu Keizaigaku Ronshu (Economic Bulletin of the Senshu University), Vol. 17, No. 2, 1983.

84) Keiso Shobo, 1983.

85) Chuokeizai-sha, 1983.

86) Business Review, Vol. 31, No. 2, Institute of Business Research, Hitotsubashi University, 1983.

87) ibid.

88) ibid.

89) ibid.

90) ibid.

91) Hitotsubashi Ronso (Hitotsubashi Review), Vol. 90, No. 3, 1983.

92) Kanagawa Kenshi, Sangyo-Keizai-hen, 1983.

93) Jochi Keizai Ronshu (Sophia Economic Review), Vol. 30, No. 1, Sophia University, 1983.

94) Hitotsubashi Ronso (Hitotsubashi Review), Vol. 90, No. 3, 1983.

95) Takushokudai Ronshu (Review of Takushoku University), No. 144, 1983.

96) Keiei Shirin (Hosei Journal of Business), Vol. 19, No. 4, Vol. 20, No. 1, Hosei University, 1982-83.

97) Keiei Shigaku (Japan Business History Review), Vol. 18, No. 1, 1983.

98) Ritsumeikan Keizaigaku (Ritsumeikan Economic Review), Vol. 32, No. 2, Vol. 32, No. 3, Vol. 32, No. 4, Ritsumeikan University, 1983.

99) Chiho Kinyu-shi Kenkyu (Historical Studies of Local Finance), 
No. 14, 1983.

100) Keizai Keiei Ronshu (Economic and Business Administration Review), Vol. 18, No. 1, Kyoto Sangyo University, 1983.

101) Sangyo Noritsu University, 1983.

Translated by Atsumi Nagatani 